\title{
Effect of Additional Threshold Inspiratory Muscle Training Preoperative on Pulmonary Complication Post Heart Valve Replacement Surgery
}

\author{
Ronni Untung Handayanto, Sri Wahyudati, Erna Setiawati
}

Department of Physical Medicine and Rehabilitation, Diponegoro University, Semarang, Indonesia

\begin{abstract}
Introduction: Cardiac surgery has been improved patient's outcome with cardiac valve anomaly. There was 111 cardiac valve replacement surgery performed in Kariadi General Hospital Semarang in 2018. Postoperative pulmonary complication (PPC) is the most common complication in this procedure compared to cardiac complication which are thought caused by the disruption of normal respiratory function as a result from surgical and anesthetic procedure. Additional preoperative threshold inspiratory muscle training (Threshold IMT) has been considered as an effective intervention to reduce PPC.
\end{abstract}

Methods: This is a quasi experimental study with main reason to know the role of Threshold IMT on PPC incidences. Subjects in the intervention group were given routine conventional rehabilitation exercises according to Clinical Practice Guide (PPK) with additional of Threshold IMT, which applied based on research protocols, while control group did conventional rehabilitation exercises only.

Results: 18 subjects were divided into intervention group $(\mathrm{n}=9)$, and control group $(\mathrm{n}=9)$, PPC incidences (Intervention group $n=2$, control group $n=7$ ) were analyzed statistically using Chi-squared test and showed significant differences (Fisher exact test $p=0.02$ with $\alpha=0.05$ ).

Conclusion: Additional of Threshold IMT preoperative may reduce the incidence of PPC on heart valve replacement surgery.

Keywords: Postoperative pulmonary complication (PPC), Threshold inspiratory muscle training (Threshold IMT) 


\title{
Pengaruh Penambahan Threshold Inspiratory Muscle Training Praoperasi Terhadap Postoperative Pulmonary Complication Pasca Bedah Ganti Katup Jantung
}

\author{
Ronni Untung Handayanto, Sri Wahyudati, Erna Setiawati
}

Departemen Ilmu Kedokteran Fisik dan Rehabilitasi, Universitas Diponegoro, Semarang, Indonesia

\begin{abstract}
ABSTRAK
Pendahuluan: Operasi bedah jantung telah memperbaiki outcome penderita dengan kelainan katup jantung. Di RSUP Dr.Kariadi Semarang terdapat 111 pasien yang menjalani pembedahan penggantian katup jantung pada tahun 2018. Paska tindakan seringkali terjadi perioperative cardiac complication dan postoperative pulmonary complication (PPC) yang disebabkan oleh penurunan fungsi pernafasan akibat efek samping tindakan pembedahan dan pembiusan. PPC lebih sering terjadi dibandingkan dengan cardiac complication. Penambahan latihan praoperasi menggunakan threshold inspiratory muscle training (Threshold IMT) merupakan intervensi yang efektif untuk menurunkan kejadian PPC.

Metode: Penelitian bertujuan mengetahui pengaruh Threshold IMT terhadap kejadian PPC dengan metode quasi experimental. Kelompok perlakuan diberikan rehabilitasi medik konvensional rutin praoperasi ganti katup jantung sesuai dengan Panduan Praktik Klinis (PPK) serta ditambahkan latihan menggunakan Threshold IMT sesuai protokol penelitian. Kelompok kontrol hanya melakukan rehabilitasi medik konvensional praoperasi.

Hasil: Didapatkan 18 subjek dalam penelitian ini, yang dibagi menjadi kelompok intervensi (n=9), dan kelompok kontrol $(n=9)$. Kejadian PPC pada akhir penelitian (kelompok intervensi $n=2$, dan kelompok kontrol $\mathrm{n}=7$ ) dianalisis secara statistik menggunakan uji Chi-square menunjukan perbedaan yang signifikan ( $\mathrm{p}=0,02$ dengan $\alpha=0,05$ ).
\end{abstract}

Kesimpulan: Penambahan latihan menggunakan Threshold IMT praoperasi dapat menurunkan kejadian PPC pada pasien pascabedah ganti katup jantung.

Kata Kunci: Postoperative pulmonary complication (PPC), Threshold inspiratory muscle training (Threshold IMT)

\section{Correspondent Detail:}

\section{Erna Setiawati, MD}

Email: roswithaerna@fk.undip.ac.id

Department of Physical Medicine and Rehabilitation, Kariadi General Hospital, Faculty of Medicine Diponegoro University

Semarang, Indonesia 


\section{INTRODUCTION}

Over the past two decades there has been a steady evolution in the practice of cardiac surgery with the introduction of "off-pump" surgery which improved the outcome and survival rate. Cardiac surgery has been improved the outcome patients with cardiac valve anomaly in the world. ${ }^{1,2}$ However, respiratory complications remain a leading cause of postcardiac surgical morbidity. The high incidence of postoperative pulmonary complications (PPC) such as pneumonia, atelectasis, pleural effusion, pulmonary oedema, respiratory failure, pneumothorax or bronchospasm are primarily in part due to the disruption of normal ventilatory function that is inherent to surgery in the thoracic region and from general anesthetic procedure. Post operatively, inhibition of respiratory muscles that contribute to pulmonary complications are thought to be caused by the incisional pain of the chest wall, and from the anesthetic procedure itself which have many effect such as altered mucociliary function which may promoted retention of airway secretion, also from administered anesthetic drug that may release circulating mediators causing bronchoconstriction and prolonged decrease in functional residual capacity up to $20 \%$ caused by decrease of respiratory muscle tone that is almost always associated with pulmonary atelectasis. ${ }^{3,4}$

Furthermore, patients undergoing such surgery often have underlying illnesses such as intrinsic lung disease (e.g., chronic obstructive pulmonary disease) and pulmonary dysfunction secondary to cardiac disease (e.g., congestive heart failure) that increase their susceptibility to postoperative respiratory problems. Given that many patients undergoing cardiac surgery are thus susceptiple to pulmonary complications, it is remarkable that more patients do not suffer from them during and after cardiac surgery. This is to a large degree because of advances in anesthetic, surgical and critical care have reduced the physiological insults of surgery. ${ }^{3-5}$

In addition, the literatures indicate the presence of physical rehabilitation on management of cardiac surgery. Physical rehabilitation consists of physical therapy that based on body movement. Physical therapy is a safe therapeutic option and considered have an important role in the multi disciplinary cardiac surgery team. These roles commonly are led by cardiopulmonary consultant physiatrist which supervised and prescribed the cardiac rehabilitation programs in preoperative and postoperative period. Cardiac rehabilitation programs are recommended by American College of Cardiology (ACC) and American Heart Association (AHA) before and after undergoing heart valve replacement surgery. It has a strong evidence that has been proved by many research in improving patient's future heart function by rehabilitation program. ${ }^{5-7}$

Recently cardiac rehabilitation programs have been showed a meaningfull development, a lot of novel strategies that can be applied to patients. Preoperative additional training using threshold IMT is a relative new method that has been proven by research provide many beneficial effects. Threshold IMT is a training that aimed to strengthen respiratory muscle with a threshold through offering of resistance which able to increase based respiratory fitness profile before cardiac surgery, that may improve patient's outcome and reduce PPC. ${ }^{8,9}$

Despite many evidences that have been published, but there was still no study conduct in Indonesia 
which assessed the effect of preoperative cardiac rehabilitation with additional training using threshold IMT on PPC incidence in heart valve replacement surgery patients. Although establishment of cardiac surgery multidisciplinary team has caused a decreased in PPC recent years, these are still heavily related to patient morbidity which may resulted in longer lengths of hospitalization, which impacts on patients, families and increased medical expenses. ${ }^{5,10}$

Preoperative IMT is a feasible intervention and seems to have a prophylactic effects aginst PPC's. These facts stimulated authors to start a study and research on this topic, to developed the cardiac rehabilitation in public health system.

\section{METHODS}

This is a quasi experimental study with main reason to know the role of Threshold IMT on PPC incidence. The study was held on July until November 2019 physical medicine and rehabilitation (PM\&R) unit, intensive cardiac care unit, and Elang cardiac care ward, in Kariadi General Hospital. The subjects recruited were all patients who did cardiac valve replacement surgery which are suited in inclusion and exclusion criteria of the research. Sample size required each group were counted as minimal as 7 persons each group.

Inclusion criteria of age ranged between 20-55 years old, normal cognitive function (Mini Mental State Examination score $>24$ ), there were no neurological deficit, with muscle strength measured using manual muscle test (MMT) scored 5 on upper and lower extremities muscle groups, daily activity with capacity of minimal 2 metabolic equivalent of tasks (METS), BMI Asia Pasific criteria under
$25 \mathrm{~kg} / \mathrm{m}^{2}$, no contraindication of using threshold IMT such as patients with bullae/blebs especially in COPD which are in risk of barotrauma and also in patients with unstable asthma, from echocardiography examination there were no symptoms of atrial fibrillation with rapid ventricular response (RVR), while in heart's chamber must be absent of vegetation and thrombus.

The exclusion criteria were having other congenital heart disease and coronary heart disease, patients undergoing more than 1 procedure of cardiac surgery in the same time except of cardiac valve replacement surgery, heart failure symptoms above scale of class 2 based on New York Heart Association (NYHA) criteria, having a pulmonary disease such as pneumonia, tuberculosis, obstructive pulmonary disease, and asthma, having some condition in musculoskeletal system which caused difficulty in walking, and those who were unwilling to participate in this study, malignancies, and subject's refusal with all reason.

The drop out criteria were patient did not perform cardiac rehabilitation exercise or respiratory training using threshold IMT more than 3 consecutive days, no longer willing to take part or did not finish the research protocols which are established, or at the end of phase 1 cardiac rehabilitation phase did not achieved functional capacity of minimal 3 METS, such complication (e.g., septic shock, cardiogenic shock with all caused, stroke) and death (most extreme).

In present study subjects recruited in research were taken using consecutive sampling which every subject meeting the criteria of research is selected until the require sample size is achieved. Subjects divided into two groups. First were interventional group and the rest were allocated in control group. 
Study pathway were held based on research protocols, starting from taking basic patient's data that were required from anamnesis, physical examination, functional capacity examination using 6MWT, and spirometry test that were performed one day before the intervention started.

All datas in this research were collected and analyzed descriptively and showed in following table presented frequency distribution. To knowing the relation between two variables the datas were analyzed statistically. Chi-square test were performed using SPSS application 15.0. in computer to test the hypothesis with a significant value $\alpha=0,05$. If there were no points under 5 in $2 \times 2$ table the result will be using Continuity Correction, instead if there were points under 5 in $2 \times 2$ table the result valid will be used Fisher's Exact Test, with significant result $p$ value must be $<0,05$.

This study has been passed the ethical clearance test by Ethical Commision Kariadi General Hospital with the number of ethical clearance letter Number 183/EC/KEPK-RSDK/2019.

Pre-operative conventional rehabilitation exercises for both group were performed with training protocols below, based on hospital clinical practice guide (PPK) in Kariadi General Hospital:

1. Breathing exercises consisting of 10 deep breathing attempts (diaphragmatic breathing and pursed lip breathing)

2. Effective coughing exercises.

3. Instruction of neck and shoulder mobilization exercises with an emphasis on thoracic extension and rotation.

4. Instruction of endurance exercise which prescribed based on the $6 \mathrm{MWT}$ result test.

5. Ankle pumping exercise.
The intervention group got an additional intervention using threshold IMT 2 weeks prior to surgery, which were prescribed two sessions per day with initial break between session minimally 8 hours each day, done approximately in 10 minutes, with training intensity $5 \times 10$ repetition, started with $40 \%$ resistance of 10 repetition maximum (RM), applied with 1-minute rest in between every 10 repetition. This exercise aimed for inspiratory muscle strengthening, while the control group were only got a conventional rehabilitation exercise based on PPK. Rehabilitation programs were conducted for 14 days before the surgery in both groups.

There were reassesment of the threshold IMT resistance dose for $10 \mathrm{RM}$ on day $8^{\text {th }}$ of intervention. All subjects have had an additional resistance that is set to their threshold IMT devices. Additional dose was given considered on subject's personal toleration.

All the subjects undergoing heart valve replacement surgery were given the same post surgery rehabilitation. The rehabilitation procedures were carried out as follows:

1. Techniques to cleanse the lungs including early mobilization, manual techniques, and active cycle of breathing techniques;

2. Active movement of the extremities;

3. Breathing exercises, expansion of the lobes of the lungs using voldyne incentive spirometer training;

4. Coughing exercise for management of sputum and airway clearance.

The criteria used for the diagnosis of PPC in this research can be seen in table $1 .{ }^{11}$ 
Table 1. PPC diagnostic criteria

\begin{tabular}{|c|c|}
\hline Pneumonia & $\begin{array}{l}\text { Clinician decision to } \\
\text { commence antibiotics for } \\
\text { suspected pneumonia based } \\
\text { on two or more of chest } \\
\text { radiograph evidence of } \\
\text { infiltration; fever }>38^{\circ} \mathrm{C}, \\
\text { leukocytosis }>12 \times 10^{9} \mathrm{~L}^{-1} \text {; } \\
\text { and purulent sputum }\end{array}$ \\
\hline Atelectasis & $\begin{array}{l}\text { Chest radiograph evidence } \\
\text { of lung opafication and } \\
\text { mediastinal shift }\end{array}$ \\
\hline Pleural Effusion & Chest radiograph evidence \\
\hline Pneumothorax & Chest radiograph evidence \\
\hline $\begin{array}{l}\text { Requirement } \\
\text { for escalation to } \\
\text { higher levels of } \\
\text { respiratory support }\end{array}$ & $\begin{array}{l}\mathrm{FiO}_{2} 0,6 \text { to maintain } \mathrm{PaO}_{2} \\
8-10 \mathrm{kPa} \text { and/or } \mathrm{SpO}_{2} 95 \% \text {; } \\
\text { requirement for nasal high- } \\
\text { flow oxygen, Continuous } \\
\text { positive airway pressure } \\
\text { (CPAP), non-invasive } \\
\text { ventilation; or the need for } \\
\text { tracheal re-intubation except } \\
\text { where a patient is required to } \\
\text { return to operating theatre for } \\
\text { further surgery }\end{array}$ \\
\hline
\end{tabular}

PPC:Postoperative Pulmonary Complication

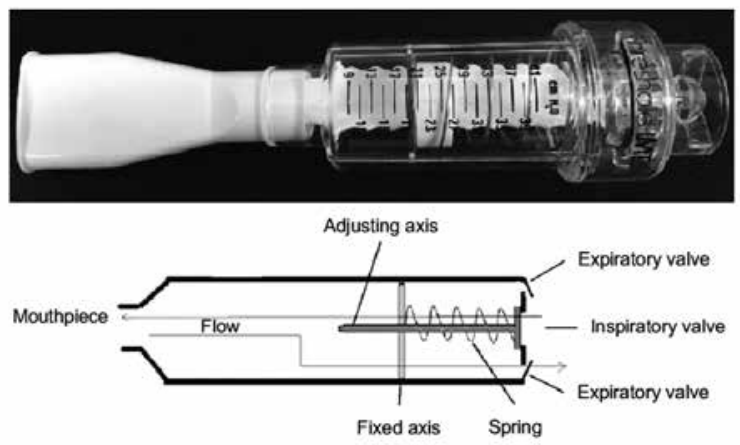

Figure 1. Threshold IMT devices used ${ }^{12}$

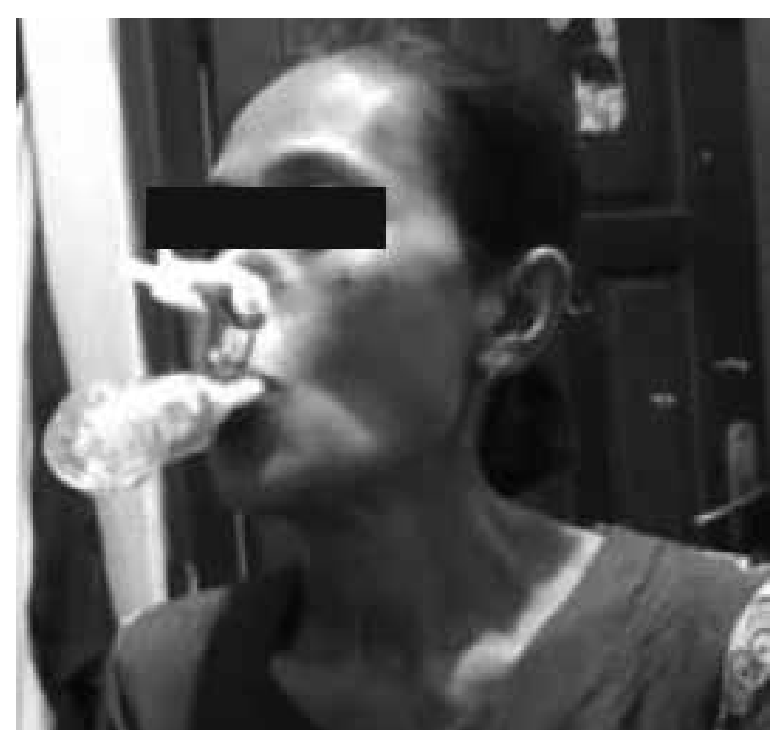

Figure 2. Patient performed inspiratory muscle training using threshold IMT

\section{RESULT}

Twenty-six candidates were recruited in this study, but 8 patients were excluded for various reasons, including coincidence of metastatic malignant disease of the lung, idiopatic postsurgical acute tetraplegia, double procedure cardiac surgery, and drop out from intervention. In the end of the study there were 18 subjects recruited which then allocated into two groups separately (intervention group $n=9$ ) (control group $n=9$ ). In this study there were no statistically significant differences between group's variables. All the subjects in this study were concluded on heart failure NYHA class II with an underlying intervention performed were ( 7 in each group for mitral valve replacement, and 2 in each group for double valve replacement). Other variables present in the subjects (as seen in table 2; e.g. age, anthropometric measurement, hemodynamic profile, medication, and physical activity base line) all were analyzed statistically showing no significant differences between groups, pointed by this result the subject's characteristic were 
meaned homogeneous between groups so the confounding variable can be controlled.

The incidence of PPC between groups were reported statistically difference between group as seen in table 3 , there were 2 incidences $(22.22 \%$ ) of PPC in interventional group, there were reported 2 subjects with pleural effusion in this group. In the control group PPC incidence were reported on 7 patients $(77.78 \%)$. PPC reported in this group were 3 subjects with pleural effusion, 2 subjects with pneumonia, 1 subject with atelectasis, and 1 subject with acute respiratory distress syndrome.

From the statistic analysis which were analyzed using Chi-square test on the result of this study showed a significant difference with $\mathrm{p}$ value $=0.02$ which are under the $\alpha=0.05$ (Table 3 ). This result highlights the effectiveness of additional threshold IMT training on conventional rehabilitation compared with conventional rehabilitation exercise alone to reduce incidence of PPC on patients undergoing heart valve replacement surgery.

Table 2. Comparation of subjects characteristic between groups

\begin{tabular}{|c|c|c|}
\hline Variable & Interventional Group $(n=9)$ & Control Group $(n=9)$ \\
\hline \multicolumn{3}{|l|}{ Sex } \\
\hline Male & $5(55.6 \%)$ & $4(44.4 \%)$ \\
\hline Female & $4(44.4 \%)$ & $5(55.6 \%)$ \\
\hline Age (year) & $45 \pm 10.20$ & $38.44 \pm 9.00$ \\
\hline $\operatorname{IMT}\left(\mathrm{kg} / \mathrm{m}^{2}\right)$ & $20.37 \pm 4.69$ & $22.54 \pm 3.78$ \\
\hline ECG-AF & $5(55.6 \%)$ & $8(88.9 \%)$ \\
\hline LV-EF \% & $66.33 \pm 8.08$ & $62.89 \pm 9.21$ \\
\hline HR & $72.00 \pm 7.94$ & $83.33 \pm 15.13$ \\
\hline SBP & $112.22 \pm 9.72$ & $110.56 \pm 8.82$ \\
\hline DBP & $68.89 \pm 7.82$ & $70.22 \pm 5.04$ \\
\hline Oxygen Saturation & $98.11 \pm 0.60$ & $98.44 \pm 0.53$ \\
\hline \multicolumn{3}{|l|}{ Medication } \\
\hline Diuretic & $5(55.6 \%)$ & $5(55.6 \%)$ \\
\hline ACEi & $1(11.1 \%)$ & $2(22.2 \%)$ \\
\hline $\mathrm{ARB}$ & $3(33.3 \%)$ & $2(22.2 \%)$ \\
\hline Digoxin & $7(77.8 \%)$ & $5(55.6 \%)$ \\
\hline B-blocker & $7(77.8 \%)$ & $7(77.8 \%)$ \\
\hline Warfarin & $7(77.8 \%)$ & $8(88.9 \%)$ \\
\hline Physical Activity (METS) & $3.88 \pm 0.77$ & $3.87 \pm 0.68$ \\
\hline
\end{tabular}

Variables are presented in mean value \pm standart deviation and percentage, significant if $p$ value $<0.05$; All variables reported between groups are equal and not significantly different that were analyzed using Chi square test; ECG: Electrocardiogram; AF: Atrial Fibrilation; LV-EF: Left Ventricle Ejection Fraction; METS: Metabolic Equivalent. 
Table 3. Statistical Analysis the role of additional threshold IMT on PPC incidence subjects undergoing heart valve replacement surgery using $t$ test

\begin{tabular}{lcccc}
\hline \multicolumn{1}{c}{ Additional threshold IMT } & PPC & \multicolumn{2}{c}{ Without PPC } \\
\hline Interventional group & N & \% & n & $77.78 \%$ \\
Control group & 2 & $22.22 \%$ & 7 & $22.22 \%$ \\
Total & 7 & $77.78 \%$ & 2 & $100 \%$ \\
\hline
\end{tabular}

*IMT:Inspiratory Muscle Training *PPC:Postoperative pulmonary complication

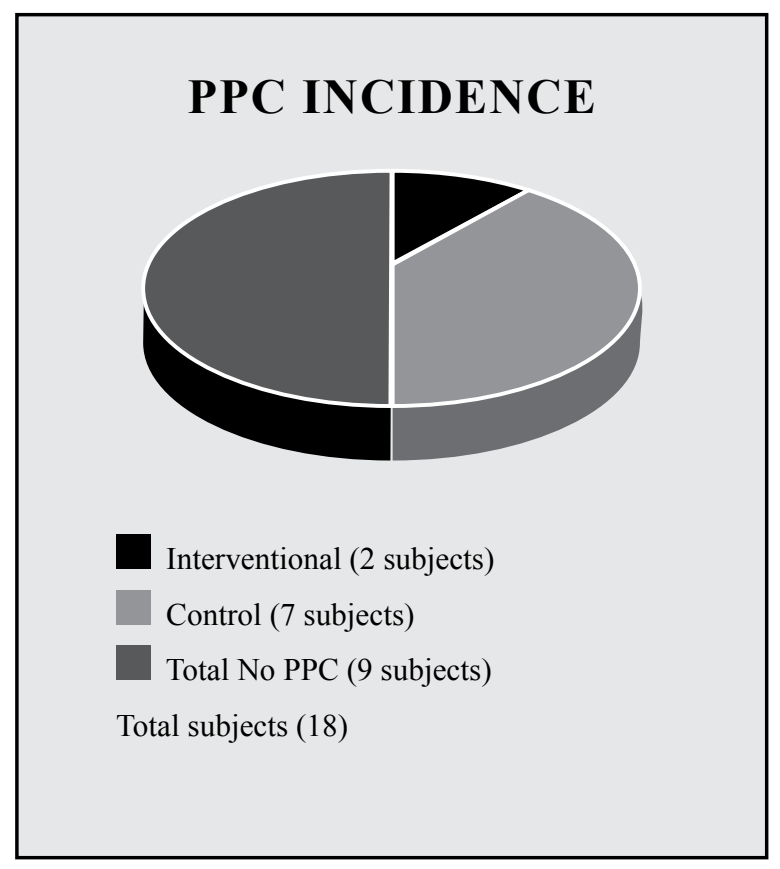

Figure 3. Pie chart Postoperative Pulmonary Complication (PPC) incidence

\section{DISCUSSION}

This is the only studies on preoperative intervention using additional threshold IMT in subjects undergoing cardiac valve replacement surgery in correlation with PPC incidence in Indonesia. The results of this study interventional group showed a fewer incidence of PPC $n=2(22.22 \%)$ as compared with control group incidence of PPC $\mathrm{n}=7(77.78 \%) .{ }^{9}$ Total incidence of PPC in this study were 9 out of 18 subjects $(50 \%)$. The process of improving functional capacity of cardiorespiratory system to withstand an incoming stressor has been proven to produce a better outcome, as seen in patients with lower functional capacity of the cardiorespiratory pre-operatively have been demonstrated higher morbidity and complication rates. This study finding on PPC incidence were similar with previous study by BrooksBrunn et al., which had reported an incidence of PPC varies within $20 \%$ to $95 \%$ after cardiac surgery. ${ }^{13}$ Cardiac surgery represents a major stressor for patients, causing loss of muscle mass, deconditioning, hypoxaemia, and changes in the respiratory system (during and after the surgical intervention) occured as a result of the effects of anaesthetics, analgesia and include changes in lung volumes due to diaphragmatic dysfunction and decrease in respiratory muscle strength. ${ }^{3,5,14}$ Another review study by Hulzebos et al. explained patients undergoing thoracic surgery were in high risk of developed postoperative pulmonary complications. A prehabilitation programs aimed to improving respiratory function are most likely to benefit in these patients. ${ }^{8}$

A study by Ferreira et al. have shown the 
benefit of IMT applied preoperative in cardiac surgery. IMT is a procedure used to increase the inspiratory muscle strength developed with a threshold IMT. Inspiratory muscle recruitment was increased with the usage of this device. These effects were offered by an additional resistance to inspiration process. The training was done with a certain percentage load according to the maximum inspiratory pressure (MIP) of the patient, which usually varying between $30-40 \%$. This study on IMT reported strength and endurance improvement of the inspiratory muscles, which may improve oxygenation, increase autonomous regulation and reduce PPC (atelectasis and pneumonia due to the decreased time to extubation). It was also observed that a shorter duration of mechanical ventilation usage decreased the length of hospitalization and the risk of death in older patients. ${ }^{15}$ According to the result of the previous research, it can be summarized that additional threshold IMT has shown the same beneficial on this research, which the result of PPC incidence in this study were significantly different between groups ( $\mathrm{p}$ value $=0.02$ ) There was limitation on this study because of the method applied was quasi experimental design study. This method was lack of blinding and randomization which may increases the possibility for producing non-equivalent group. However, quasi experimental were still consider a reliable study especially in surgical intervention assessment study. In this study, demographic factor and non-controlled variable has been analyzed statistically and resulted a homogenous characteristic among subjects.

\section{CONCLUSION}

Additional Threshold IMT preoperative may reduce PPC incidence on patients with heart valve replacement surgery.

\section{REFERENCES}

1. Li J, Gu C. Off-pump mitral valve repair: Primary result of treating moderate ischemic mitral regurgitation during off-pump coronary artery bypass grafting. J Thorac Dis. 2019;11(7):3191-4.

2. Goldfarb M, Drudi L, Almohammadi M, Langlois Y, Noiseux N, Perrault L, et al. Outcome reporting in cardiac surgery trials: Systematic review and critical appraisal. J Am Heart Assoc. 2015;4(8):1-9.

3. Agostini P, Cieslik H, Rathinam S, Bishay E, Kalkat MS, Rajesh PB, et al. Postoperative pulmonary complications following thoracic surgery: Are there any modifiable risk factors? Thorax. 2010;65(9):815-8.

4. Weissman C. Pulmonary complications after cardiac surgery. Semin Cardiothorac Vasc Anesth. 2004;8(3):185-211.

5. Perelló-Díez M, Paz-Lourido B. Prevention of postoperative pulmonary complications through preoperative physiotherapy interventions in patients undergoing coronary artery bypass graft: literature review. J Phys Ther Sci. 2018;30(8):1034-8.

6. Shakuri SK, Salekzamani Y, Taghizadieh A, Sabbagh-Jadid H, Soleymani J, Sahebi L. Pulmonary physiotherapy effect on patients undergoing open cardiac surgery. Russ Open Med J. 2014;3(3):4-7. 
7. Shakuri SK, Salekzamani Y, Taghizadieh A, Sabbagh-Jadid H, Soleymani J, Sahebi L, et al. Effect of Respiratory Rehabilitation before Open Cardiac Surgery on Respiratory Function: A Randomized Clinical Trial. J Cardiovasc Thorac Res. 2015;7(1):13-7.

8. Hulzebos EH, Smit Y, Helders PP, van Meeteren NL. Preoperative physical therapy for elective cardiac surgery patients. Cochrane Database Syst Rev. 2012;(11).

9. Paramitha A, Wahyudati S, Wiryawan W, Sofia SN. Pengaruh Threshold Inspiratory Muscle Training Praoperasi terhadap Kebugaran Kardiorespirasi Pascabedah Ganti Katup Jantung. Medica Hosp J Clin Med. 2020;7(1):82-90.

10. Fernandez-Bustamante A, Frendl G, Sprung J, Kor DJ, Subramaniam B, Ruiz RM, et al. Postoperative pulmonary complications, early mortality, and hospital stay following noncardiothoracic surgery: A multicenter study by the perioperative research network investigators. JAMA Surg. 2017;152(2):15766.
11. Moore JA, Conway DH, Thomas N, Cummings D, Atkinson D. Impact of a perioperative quality improvement programme on postoperative pulmonary complications. Anaesthesia. 2017;72(3):317-27.

12. Wu W, Zhang X, Lin L, Ou Y, Li X, Guan L, et al. Transdiaphragmatic pressure and neural respiratory drive measured during inspiratory muscle training in stable patients with chronic obstructive pulmonary disease. Int J COPD. 2017;12:773-81.

13. Brooks-Brunn JA. Postoperative atelectasis and pneumonia. Heart Lung - J Acute Crit Care. 1995;24(2):94-115.

14. Miskovic A, Lumb AB. Postoperative pulmonary complications. $\mathrm{Br} \mathrm{J}$ Anaesth. 2017;118(3): 317-34.

15. Ferreira PEG, Rodrigues AJ, Évora PRB. Effects of an inspiratory muscle rehabilitation program in the postoperative period of cardiac surgery. Arq Bras Cardiol. 2009;92(4):261-8. 